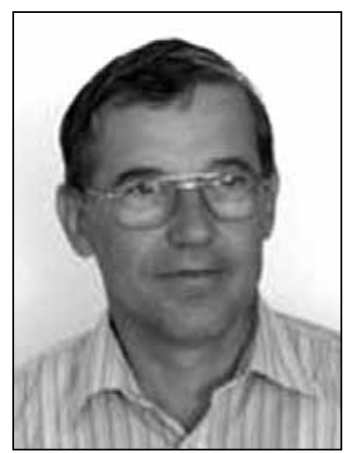

\author{
Prof. Juraj Nemec, prof. Matej Bel \\ University Banska Bystrica, Slovakia
}

\title{
Health Policies versus Health Care Reforms and their Success in Central and Eastern Europe
}

\section{Introduction}

After 1989 all Central and Eastern Europe - CEE (including Commonwealth of Independent States CIS) countries realized large scale health care reforms. Reform measures were slightly different, but the general goals very similar - optimum efficiency/equity trade off and improved quality. Existing evaluations from different sources (WHO, World Bank, OECD, IMF, NISPAcee, LGI and many others) clearly indicate that many reform expectations were not achieved and fulfilled.

There exists one obvious factor for limited success of health care reforms in CEE region - lack of financial resources (connected with the limited of capacity to use these limited inputs in effective and efficient way) - this issue is just briefly mentioned in our analysis. The main focus is on the other selected barrier for success - health policy making and implementation area. We try to respond to questions like: „Is there any real health policy in most of CEE countries - can effective reform be drafted? Are/can the concrete reforms measures be effectively implemented? Does the real, policy analysis based, feedback exist?

Our analysis is based on examples from many countries in the region, obtained by the secondary analysis of existing documents. The focus will be the most developed area - new EU members, especially Slovakia and the Czech Republic, but less developed CIS countries will be included, too.

\section{Health care reforms in CEE countries and their outcomes}

Health care reforms in CEE are described and evaluated by the comprehensive list of different authors. FuenzalidaPuelma (2002) provides relatively comprehensive overview of their earlier works; more recent books like Shakarashvili (2005), Rosenbaum-Nemec-Tolo (2004), Scheffler-Potucek (2008) and studies like VerhoevenGunnarsson-Lugaresi (2007) might be added. Because of this fact we just briefly summarize well known findings.
As first we have to mention that the pre-reform the situation was very similar in all CEE countries. This common starting situation is unsurprising, for all countries in the region except Yugoslavia and Albania were members of the Soviet bloc, with almost identical societal and economic structures. The initial health care differences reflected genuine variations in performance. For example when transition began the Czechoslovak and Hungarian health care systems were far from the crisis states of the Polish (Millard, 1994) and Soviet systems (Davis 1993, 2001). It is also worth noting that despite the proclaimed guarantee of free medical assistance regardless of social status, the practice of unofficial extra payments to receive good medical treatment was common. Only the scale of this "shadow economy" differed across countries.

The concrete changes and the timeframe of their realization after 1989 differ between the CEE countries, depending very much on the specific conditions at the start of the reforms and during their implementation. However, there are some common issues across the health reforms in CEE countries - most notably the introduction of several market-based instruments to replace the 'socialist' health care delivery systems and the increased role of self-governments in health care delivery. The most important market linked changes were the introduction of health insurance financing systems to replace a general taxation-based model, privatization, and the introduction of private payments/co-payments. Perhaps the main difference in reform approaches concerned access guarantees.

After 1989 soon or later almost all CEE countries introduced a Bismarckian system of social health insurance to replace the previous general taxation finance system. The differences between CEE countries lie in their concrete approaches. Few countries started by introducing pluralistic insurance systems, with public and private insurance companies. Typical examples in the 


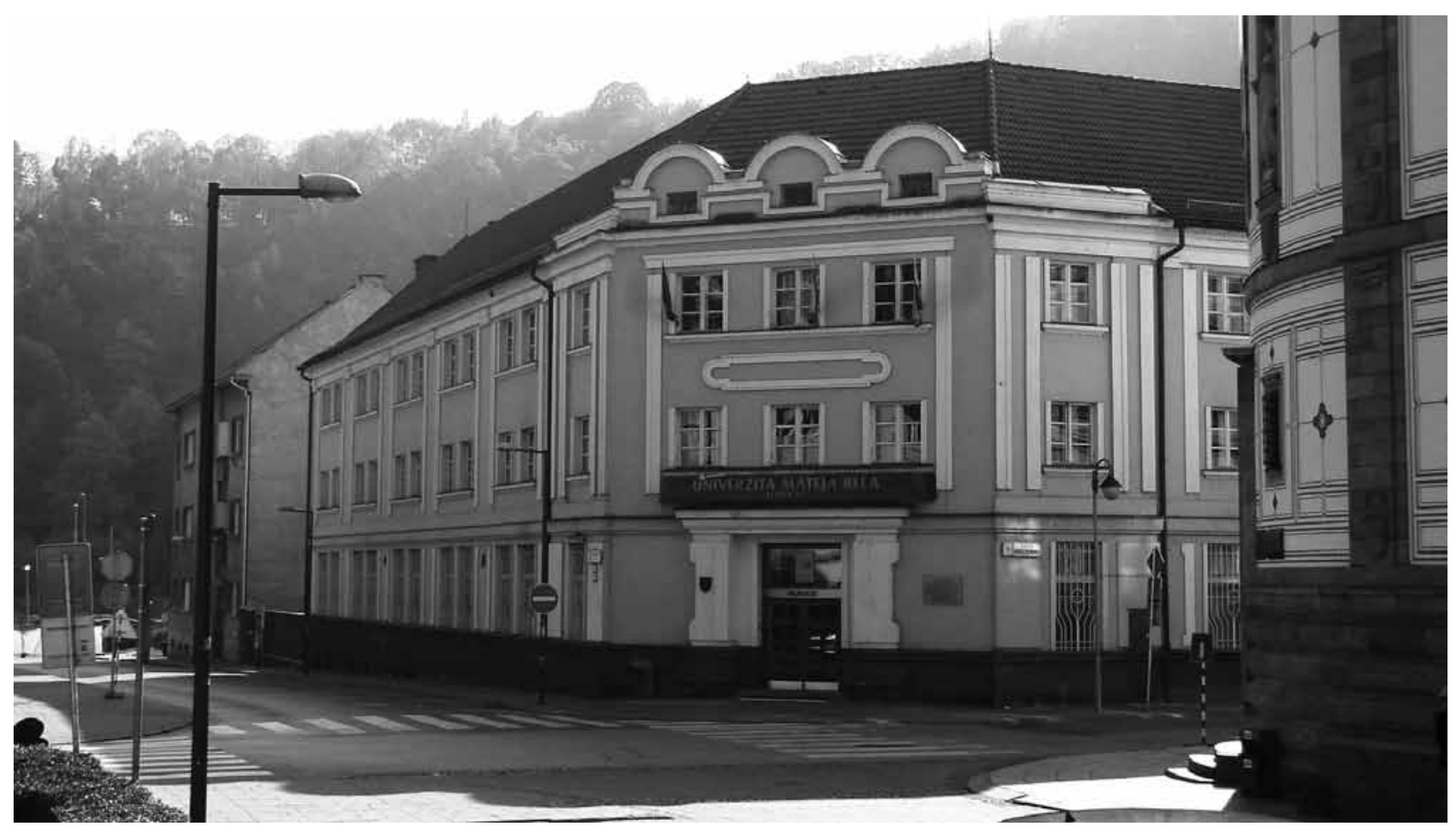

mid 1990s were the Czech Republic with 26 companies and Slovakia with 13 companies. Almost all other countries - Bulgaria, Croatia, Estonia, Hungary, Latvia, Lithuania, Macedonia, Poland, Romania, Slovenia and Serbia opted for a single public sector insurance company with local and regional branches. Similar systems were also established in most CIS states, though some of them - Russia is the major example - opted for a mixed system, where a range of public sector actors - the state insurance company, the federal state and regions pay for free at point-of-use services (Chubarova, 2004).

Concerning privatization almost all countries accepted that the primary care, specialized ambulatory care and pharmacy sectors should belong to the private sector, and privatization has been or is almost completed. The difference is connected with the hospital sector. In some countries, for example Czechia, most hospitals still remain public bodies, governed by the central government and local governments. In other countries, for example Armenia, hospitals were transformed into semi-public non-profit organizations. In Georgia - as an outcome of the health care reform - all health care institutions are now independent legal entities. They function as either private or joint stock companies and are administratively and financially autonomous from the state budget (Sumbadze and Dolidze, 2004). For profit hospitals are still exemption in the region.

Concerning access policies, two groups of countries can be distinguished in the CEE region:

- Those continuing to focus on universal access as a key principle of the health sector, and:

- Those where access is no longer guaranteed.

The first group comprises mainly countries in Central Europe that are now European Union members. Their internal policies, but also EU universal health care coverage principles, for example expressed by the
European Charter of Social Rights, motivate countries like Czechia, Slovakia, and Hungary to maintain as much universal access as possible. In countries where public funds to finance health expenditures were quite inadequate, the policy of universal access needed to be officially rejected. A good example is Ukraine, which in 2000 spent only $2.7 \%$ of GDP on health. Consequently Ukrainian experts have argued that only $30 \%$ of the population's minimal medical needs are being met. As a result no national healthcare programmes are being fully implemented (Khadzhyradeva - Kolisnichenko, 2004).

Access is to some extend connected with the decisions on public - private share in financing the care. Approaches again differ significantly. A relatively high proportion of public financing of health care expenditures is still a common feature of the most developed countries, currently EU members, with two extreme cases - the Czech Republic and Slovakia. The other extreme cases are mostly from NIS countries, where the share of private payments increased significantly. The government regulations are related only to the (insufficient) publicly financed services, while the rest of the system develops in a non-regulated way, with increasing costs and decreasing accessibility. The relative amount of public expenditures for health care in Russia fell from 4,4 \% GDP in 1997 to 3,3 \% of GDP in 2003. This gap was only partly filled by private resources so in total fewer services were available.

\section{1. Reform outcomes}

It is very difficult to assess the level of success of any reform measure. Experts, but mainly politicians always want to show reform outcomes from their political (professional) point of view. Frequently their opinion on the same problem dramatically differs. There is no chance to find the same voice, as values used and goals of evaluation normally differ. 
To be as much objective as possible, the base for our analysis is relatively widely used WHO (2001 - Table 1) approach, focusing on three main group performance dimensions - health status of inhabitants, fairness/access and costs. In our paper we will use a similar approach, assessing the outcomes of health reforms in the CEE region by the following criteria:

1. Health status.

2. Access to health services.

3. Efficiency.

Table 1

Ranking of Health Care Systems: Selected Countries

\begin{tabular}{|c|c|c|c|c|}
\hline & Overall & Health & Fairness & Cost \\
\hline France & 1 & 4 & 26 & 4 \\
\hline $\begin{array}{c}\text { United } \\
\text { Kingdom }\end{array}$ & 18 & 24 & 8 & 26 \\
\hline Germany & 25 & 41 & 6 & 3 \\
\hline USA & 37 & 72 & 54 & 1 \\
\hline Slovenia & 38 & 62 & 82 & 29 \\
\hline $\begin{array}{c}\text { Czech Re- } \\
\text { public }\end{array}$ & 48 & 81 & 71 & 40 \\
\hline Poland & 50 & 89 & 150 & 58 \\
\hline Slovakia & 62 & 88 & 96 & 45 \\
\hline Hungary & 66 & 105 & 105 & 59 \\
\hline Estonia & 77 & 115 & 145 & 60 \\
\hline Russia & 130 & 127 & 185 & 75 \\
\hline
\end{tabular}

Source: World Health Organization, 2001.

Health status is normally measured by standard outcome indicators, especially life expectancy, infant and child mortality and death rate. One of the most complex sources for such comparison is the World Bank World Development Indicators. Selected data from this source are presented in the Table 2 .

Table 2

Health status indicators - selected CEE countries

\begin{tabular}{|c|c|c|c|c|c|c|}
\hline \multirow{2}{*}{ Country } & \multicolumn{2}{|c|}{$\begin{array}{c}\text { Life expectancy } \\
\text { at birth }\end{array}$} & \multicolumn{2}{c|}{$\begin{array}{c}\text { Infant mortality } \\
\text { rate }\end{array}$} & \multicolumn{2}{c|}{$\begin{array}{c}\text { Under } 5 \text { mor- } \\
\text { tality rate }\end{array}$} \\
\cline { 2 - 7 } & 1990 & 2004 & 1990 & 2004 & 1990 & 2004 \\
\hline Armenia & 68 & 71 & 52 & 29 & 60 & 32 \\
\hline Bulgaria & 72 & 72 & 15 & 12 & 19 & 15 \\
\hline Croatia & 72 & 75 & 11 & 6 & 12 & 7 \\
\hline Czechia & 71 & 76 & 11 & 4 & 13 & 4 \\
\hline Estonia & 69 & 72 & 12 & 6 & 16 & 8 \\
\hline Georgia & 70 & 71 & 43 & 41 & 47 & 45 \\
\hline Hungary & 69 & 73 & 15 & 7 & 17 & 8 \\
\hline Kazakhstan & 68 & 65 & 53 & 63 & 63 & 73 \\
\hline Kyrgyzstan & 68 & 68 & 68 & 58 & 80 & 68 \\
\hline Latvia & 69 & 71 & 14 & 10 & 18 & 12 \\
\hline Lithuania & 71 & 72 & 10 & 8 & 13 & 8 \\
\hline Macedonia & 72 & 74 & 33 & 13 & 38 & 14 \\
\hline
\end{tabular}

\begin{tabular}{|c|c|c|c|c|c|c|}
\hline Moldova & 68 & 68 & 30 & 23 & 40 & 28 \\
\hline Poland & 71 & 74 & 19 & 7 & 18 & 8 \\
\hline Romania & 70 & 71 & 27 & 17 & 31 & 20 \\
\hline Russia & 69 & 65 & 23 & 17 & 29 & 21 \\
\hline Slovakia & 71 & 74 & 12 & 6 & 14 & 9 \\
\hline Slovenia & 73 & 77 & 8 & 4 & 10 & 4 \\
\hline Tajikistan & 63 & 64 & 92 & 75 & 119 & 93 \\
\hline Turkmenistan & 63 & 63 & 80 & 80 & 97 & 103 \\
\hline Ukraine & 70 & 68 & 19 & 14 & 26 & 18 \\
\hline Uzbekistan & 69 & 67 & 65 & 57 & 79 & 69 \\
\hline Europe:EMU & 76 & 79 & 8 & 4 & 9 & 5 \\
\hline
\end{tabular}

Source: http://devdata.worldbank.org/wdi2006

The data in Table 2 show distinctly different patterns for the health status of CEE residents - in some countries, health is improving, but in others it is unchanged or is significantly declining. Only a few CEE countries, for example Slovenia and the Czech Republic are close to the EU average. Although a country's health care system has only a limited impact on the health status of its inhabitants (the potential of health care financing to influence health status is estimated to be between 10 and 20 percent - for example see Pazitny, 2006), some links do exist. A lack of financial resources, including financial resources for health, and a citizen's lifestyle (with no resources to change or influence it), are likely to be among the most important factors underlying these life expectancy differences.

As already noted, from the point of view of access there are two groups. Richer countries in Central Europe, especially the Czech Republic and Slovakia try to assure equal quality access for all, predominantly financed from public resources. The success is only partial, as the existence of shadow economy (Miller et al., 1998) is the source of differences in real access. Countries that lack resources, including all the CIS countries, could not continue their pre-reform policies of universal access. Some of them still formally aspire to universal access others have entirely abandoned this objective. A typical example from the first group is Ukraine. Formally, according to its health reform strategy, Ukraine has focused on achieving economic effectiveness and providing quality medical care, while at the same time preserving accessibility for its entire population. However in practice the government has been unable to maintain universal access. Access is increasingly limited because of insufficient public funds and the transition to a system of private payment. These factors have shrunk the network of medical institutions available to citizens and led to a shortage of (free) medicines for the sick, as well as a constant fear of ill health, inadequate treatment and even total impoverishment (Khadzhyradeva - Kolisnichenko, 2004).

An example from the second group is Georgia. After the reform the state finances only a limited number of programs. Public expenditures on health care as a percentage of GDP fell from $4.1 \%$ in 1991 to $0.59 \%$ in 1999 . In 2001 these expenditures were US\$7.30 per capita. In Georgia, the 
number of people covered by health insurance is negligible $-615,165$ out of a population of about 5 million, or about 12.3\% (Sumbadze and Dolidze, 2004).

Measuring efficiency is not a simple task, especially in health care, where outcomes are not directly related to health expenditure. In our case we try to focus on its cost-containment dimension and we include only more developed systems, predominantly financed from public resources and guaranteeing universal access. The reason is obvious - countries with public care health expenditures of 5-10 USD per capita simply cannot be assessed by this criterion.

All sources analyzing the cost containment aspects of CEE health systems paint the same picture - in spite of manyformal reform goals, real transformation to a modern structure of health care delivery is still to be achieved. The most visible outcome of the very limited cost-containment capacity is expenditures for pharmaceuticals. The costs for drugs exploded after 1990 in all transition countries. This is partly explained by the increased use of effective but more expensive imported medicines. But it is also caused by an ineffective regulatory system for drug prescription. The tools of evidence-based medicine are still not used for determining which medicine to prescribe, to whom and under what circumstances. This leaves an opening for lobbying by pharmaceutical firms, bribing doctors to prescribe more and more expensive drugs than necessary. In this ineffectively regulated environment the costs of drugs is almost equivalent to the remaining costs of the hospital system.

Most CEE countries try to control health costs via reimbursement mechanism, however such procedure cannot function in the environment where adequate information systems to track costs, established negotiation processes are not developed enough and standards are not used (Shakarashvili, 2005).

\section{Limited resources and limited efficiency of their use: obvious factors limiting reform success}

Before we come to the core of our analysis, it is necessary to stress that CEE countries in say the 1980s had very «modest» levels of income per capita in comparison to OECD states, and that this picture has only begun to change (in some of them) very recently as they have begun to narrow the gap with the older EU members. So the hope that improved health outcomes were attainable until recently must have rested on one or more of the following ideas:

1. An improvement in efficiency was possible after 1989 that would not be hidden by a fall in resources from the transformational recession of the 1990s.

2. A higher priority would lead to more and/or better resources being spent on health by governments and/or citizens.

3. Citizens' health would improve for some other reason - e.g. better diet, in part a result of better food choice or quality.

As we already indicated, in reality efficiency improvements were not achieved and as the proportion of GDP spent for health care in CEE increases very marginally, if at all is some countries (Belli, 2001), economic barriers of health reforms success are more than visible.

\section{Health policy considerations}

There is no doubt that lack of resources and their inefficient and ineffective use prevent to achieve most of CEE health reform goals. However, the focus of our analysis is health policy and we want to respond to three given research questions:

1. Is there any real health policy in most of CEE countries - can effective reform be drafted?

2. Are (can) the concrete reforms measures (be) effectively implemented?

3. Does the real, policy analysis based, feedback exist?

The following text will try to provide some answers and some navigation, of course other explanations and opinions may exist, especially regarding more normative aspects of the analysis.

3. 1 Is there any real health policy in most of CEE countries - can effective reform be drafted?

Several studies (like Manzmanian and Sabatier, 1989), summarized for example by Pavlík (2008), provide the list of certain main preconditions for successful policy making. From the point of view of our research we selected three of them and try to assess the level of their achievement in CEE region.

A: The existence of internal "professional" policy making capacity - local knowledge and skills.

Concerning effective "internal and professional" policy formulation, more aspects, clearly showing that this precondition was not fulfilled, can be provided:

- There is no doubt that in nineties, when most reforms started, there was real lack of general and specific expertise to set effective health reform policy no country in the world had previous experience with transformation form centrally managed and planned society to market based democratic one. The main driving force behind reforms was to depart as quickly as possible and to detach as much as possible from past as the result "the baby was thrown from the bath with the water" (Shakarashvili, 2005).

- Persons responsible for health reforms were mainly medical doctors, with limited economic background, and in some case protecting interest of medical profession (Maly, 1998).

- Many CEE governments have been mainly unstable and generally short-lived coalitions of different political groups and the ministers of health changed really frequently. The most visible case in the recent period is Poland with 8 ministers during the period 2001 - 2005 (Pazitny, 2008).

- The relation between politicians and bureaucrats was not standard, professional and sustainable system of bureaucracy was not established and administrative structures changed when the government or the minister changed (OECD, 2008).

B: The existence of appropriate external advice.

For this item we can just quote Shakarashvili (2005, pp. 13-14): "Especially at the early phases of the post- 
Soviet reforms these countries were strongly attracted by the idea of "westernization" and were open to close collaboration with international (predominantly Western funded and Western influenced) organizations. Often this collaboration, especially in the health care sector, resembled teacher-pupil type of relationships, when the CEE/CIS governments would not object to following the recommendations of external partners without questioning their validity or appropriateness for the local context, while the Western agencies were not shy to reveal a "consultant knows all" attitude. As reforming the Soviet health system was an unprecedented policy making exercise, obviously there were no prepared recipes available. The policy design recommendations were often based on the specific experience and knowledge of the international experts in their own countries elsewhere in the world. The major players in the CEE/CIS health reforms have been the World Bank, followed by USAID, $\mathrm{WHO}$, and to lesser extend by Western European governments. Thus, the American influence via the World Bank and US government funded programmes has been predominant in the region."

The Czech and Slovak reforms, establishing "competitive" health insurance system in 1993, when their financial markets did not work, is typical example of such advice, with obvious and well described outcomes (Lawson and Nemec, 2003).

The problem of lack of quality of external advice for transitional and developing countries is more and more frequently stressed by current literature (see for example articles in NISPAcee Journal of Public Administration and Public Policy), on the other hand, missing external pressure is also not effective option, as more and more countries are reluctant to change existing ineffective mechanisms (for phenomena of "post-accession crisis" see for example Agh, 2008).

C: The existence of internal "political” policy making capacity - respecting that "public policy“ and "politics“ are significantly different term and politics to policy cannot dominate in long-term perspective.

Several languages in transitional and developing countries (like Polish, Slovak, Czech) do not distinguish between "policy" and "politics" and the same is true for politicians there. As indicated for example by Agh (2008), politicians' strategy in most CEE countries today is to attract voters by short term politics. Two examples might be mentioned.

In Slovakia, new socio-democratic government elected in 2006, cancelled immediately after its establishment almost all co-payments in health care, in the situation when public health expenditures are relatively low, but pay for almost $90 \%$ of all health acre spending. As already indicated, such policy is really short term, as it does not guarantee either universal and free access, or sustainability of health finance.

Even more "crazy" issue is the Hungarian referendum on health care co-payments, initiated by right wing parties (!) in 2008 (right wing parties are expected to be in favor). This referendum was successful, voter refused co-payments and the socio-democratic government had to stop them.
Reforms are also dominantly prepared on "Cabinet" principle, without effective and open professional and public discussion. The role of universities and professional organizations in their designing is really marginal independent professional advice and reviewing is not expected and welcomed by governments, and the capacity to provide such advice is very rare.

\section{2 Are (can) the concrete reforms measures (be) effectively implemented?}

In this part we will assess selected health reform implementation considerations. We already indicated that the health policy making capacity in CEE is really weak. Could implementation capacity be higher?

A: Do main actors support effective health care reforms and their implementation?

The tool in this part is an analysis of the interests and strategies of the main actors. This analysis helps to explain why all CEE countries from this group have major problems with health care financing. The key actors and their strategies, according to opinion, are:

A: Hospitals - are normally (at least in Central Europe) unconstrained by hard budgets. Their managements are able to channel part of their finance into private pockets, and official salaries are low.

B: Doctors - are normally (at least in Central Europe) unconstrained by hard budgets, can often do what they want, using the chance for supplier induced demand in all dimensions (e.g. extra treatments, equipment and drugs). They have job control over shadow incomes to compensate for low official salaries.

C: Politicians - may benefit from providing their voters with "free" universal coverage and from many, even not realized, promises.

D: Bureaucrats - with extra resources their power increases.

E: Patients - are not well informed and hence can be persuaded to opt for better (more expensive) drugs or treatments, even if they are not needed (more than $75 \%$ citizen in Slovakia evaluated 2004 necessary reforms as bad - Pazitny, 2006).

F: Insurance companies - in most CEE countries insurance companies are not really independent and do not serve as regulators, but only as resource distribution channels. For them more resources means a higher level of overheads for their own use.

The brief overview of the strategies of all the key actors indicates that there is only one main player, which might have willingness to change the system - the government/elected politicians (for example 2004 reform in Slovakia - see Pazitny, 2006). However, as necessary reforms are not supported by other actors, changes are difficult to achieve.

Data at least from the Czech Republic and Slovakia (Nemec and Lawson, 2008) indicate that a left wing government's main goal is universal access, independent of the financial situation of the system. With such a policy the system must be imbalanced, as described by the following simple inequality: 
Supply > Resources \& Demand

Supply: government decision on scale of "free" services

Demand: the scope of "free" services demanded by patients/citizen

The deficit of the system is covered predominantly by arrears, at the expense of private suppliers (see for example Verhoeven, Gunnarsson and Lugaresi, 2007). The basic idea of such a system, where financial constraints are not binding be described by the following figure:
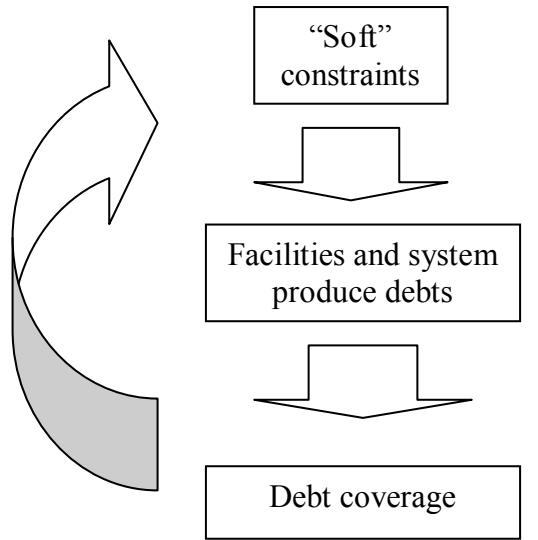

It would seem that left wing governments or governments prioritizing service delivery above cost considerations cause health systems to work in debt cycles as described above and only external constraints arising from EU membership might set some limits to the size of debts and the repetition of such cycles.

B: Strong position of a government/government coalition in the Parliament

Governments need effective support in their Parliaments to be able to pursue reform goals. However, in CEE, governments are frequently short-lived coalitions with just marginal "surplus" of votes in their national Parliament (results of Czech elections in 2007 are good example - coalition 100 mandates, opposition also 100 mandates, similar situations happened in Slovakia, Hungary or Poland).

C: Unanimity within the government coalition parties As already indicated, CEE government frequently are short lived, unstable and purpose-made coalitions. In such conditions "log-rolling" (see Stiglitz, 1989) is the way to pursue decisions, but such decisions cannot be normally effective.

\section{D: Support of reform measures by voters}

We already touched this item when discussing preferences (utility functions) of main actors. Health reforms were supported by voters in their early phase, but the situation changed. Painful changes happened only in Eastern Europe and with lack of finance the situation is difficult to improve. Main Central European states (especially Slovakia and Czechia) maintain system without effective cost-containment mechanism and their chance to introduce them is now very limited because voters would refuse them (referendum in Hungary). Possible change can be connected only with improved education of voter, who should be capable to understand, at least partly, the problem of fiscal illusion (to understand that "there is no free lunch").

The most visible case, when voters suffer because of the lack of their education is prescription of antibiotics. In most CEE countries antibiotics can be prescribed without previous test (cultivation). Patients are happy to receive expensive drugs and the result is straightforward - high consumption of antibiotics in the region and increasing resistance of microbes to them (Pazitny, 2008).

\section{E: Sufficient resources to implement the reforms}

Reforms normally need extra resources and such resources are not available in CEE region, because of low economic performance (Table 5) and low \% of health spending to GDP (World Bank, 2007).

F: Stability of political and general environment for reform implementation

The problem of short living coalitions was already mentioned. The other negative issue is deficiency of the "state of law", still persisting in CEE. Respecting law is not tradition for all actors - the statement of the director of last performing hospital (according to results of public procurement monitoring by the Transparency International Slovakia) in Trebisov: "The life of the patient is much more important than the Public Procurement Law. Our only concern is to provide the patient with maximum care". The patient does not care about the procurement of medicaments; he just wants his/her drug" (National TV, 3. 11. 2004).

G: Clear formulation of reforms goals and steps to achieve them

This precondition is also not always achieved by CEE governments. Goals are frequently just proclamations and paths to reach them not only are not formulated, but in case of proclamations just cannot be defined. The Governmental Declaration of the Slovak government from 1998 (Nemec, 2004) provides examples of such goals - equal universal access to top quality health care for all (similar case was Ukraine - see above text about access). Almost all reforms in CEE stressed the necessity to improve prevention - very few really happened, as lobbies prefer expensive treatments to cheap preventive care.

\section{3 Does the real, policy analysis based, feedback} exist?

The response to this question will be very short. According to our opinion, created on the base of several studies and own experience, unfortunately, in CEE region the chance and capacity for proper ex-post policy analysis does not exist today. Not only such attitude is not present, moreover its basic tools are not created, yet - like the use of standards, evidence based medicine and performance audit. 
1. Agh, A. (2008), Synergies and Conflicts between Policy Regimes and Political Systems. Paper presented at XVI. NISPAcee conference in Bratislava, http://www.nispa.sk/_portal/ conf_program_details.php?meeting_id=184\&cid $=16$

2. Belli,

3. Condrey, Stephen E. (1998) 'Reforming Public Management in Ukraine: Toward a University-based Public Service Delivery Model', International Journal of Public Sector Management 11(1), pp. 27-36

4. Czech Statistical Office, Statistical Yearbook of the Czech Republic. Prague: Czech Statistical Office, various issues.

5. Davis, C.M.: (1993) Russia s health reform: a complicated question, Transition, 4(7): 1-13.

6. Davis, C. (2001), “The Health Sector: Illness, Medical Care and Mortality," in Granville, B., Oppenheimer, P., eds., Russia’s Post-Communist Economy. Oxford: Oxford University Press, pp. $475-538$.

7. Dlouhy, M. (2004) An Alternative of Health System Performance Measurement in the Context of World Health Report 2000. In: Theoretical and practical aspects of public finance. CD rom. Prague: VSE.

8. EBRD, Transition Report 2007, London, EBRD.

9. Euro Health Consumer Index 2006. Health Consumer Powerhouse AB (2006). http://www.healthpowerhouse.com/media/ RaportEHCI2006en.pdf

10. Fuenzalida-Puelma,

11. Healthcare (2002). Healthcare: Georgia 2001. Statistical compendium. Tbilisi.

12. Chubarova, T. (2004) "Reforming Russian Healthcare: Social Insurance or NHS?" Health Management, N13, 3/2004.

13. Khadzhyradeva, S. and Kolisnichenko, N. (2004) Public Health Management and Policy Education and Training: Ukraine. In: Rosenbaum, A., Nemec, J. and Tolo, K. (2004) Health Care Delivery Systems. Bratislava: NISPAcee, pp. $230-280$.

14. Khachatryan, T. (2006) Public Health and the State of Healthcare in Republic of Armenia. Health Management, N19, 3/2006.

15. Lawson, C. and Nemec, J. (2003) 'The Political Economy of Slovak and Czech Health Policy', International Political Science Review 24(2): 219-36.
16. Le Grand, J. (1982), The Strategy of Equality. London, Allen and Unwin

17. Malý, I. (1998), Problém optimalní alokace zdroju ve zdravotnictví. [Optimum health resource allocation problems], Brno: Masarykova univerzita

18. Manzmanian, D.A. and Sabatier, P. A. (1989), Implementation and Public Policy. University Press

19. Millard, F.: (1994) Developments in Polish Health Care, in S. Ringen and C. Wallace (eds) Societies in Transition: East-Central Europe Today, Avebury, Aldershot.

20. Miller, W.L., Grodeland, A.B. and Koschechkina, T.Y. (1998) Are the People Victims or Accomplices. Budapest, LGI.

21. Nemec, J. (2004), 'Zdravotníctvo' [Health care], in M. Kollar and G. Meseznikov (eds) Slovakia 2004: A Global Report on the State of Society. Bratislava: Institút pre verejné otázky (IVO)

22. Nemec, J. and Lawson, C. (2005) Health Policy in Slovakia and the Outcomes of Health Care Reforms: 1989-2003. In: Journal of Comparative Policy Analysis. Vol. 7., No1, March 2005

23. Nemec, J. and Lawson, C. (2008), Health care reforms in CEE: processes, outcomes and selected explanations. In: NISPAcee Journal on Public Administration and Public Policy. Vol. 1., No1, 2008

24. OECD (2008)

25. PADCO Armenia Social Transition Program (2002) 'Report No. 87: Recommendations for Improving the Definition and Administration of the Basic Benefits Package (BBP).' Available at http://www.padco.am.

26. Pavlík, M. (2008), Implementace veřejné politiky. [Implementation of public policies], Brno: Masaryk University

27. Pažitný, P., Zajac, R. (2001), Health Care Reforms Strategy. Bratislava: M.E.S.A. 10

28. Pažitný et al. (2006), "Health Care", in Slovakia 2005. Bratislava: Institute for Public Affairs

29. Pažitný et al. (2008), "Health Care", in Slovakia 2007. Bratislava: Institute for Public Affairs

30. Rosenbaum, A., Nemec, J. and Tolo, K. (2004), Health Care Delivery Systems. Bratislava: NISPAcee

31. Shakarashvili, G. (2005), Decentralization in Healthcare. Budapest: OSI-LGI

32. Scheffler, R. and Potucek, M. (2008)

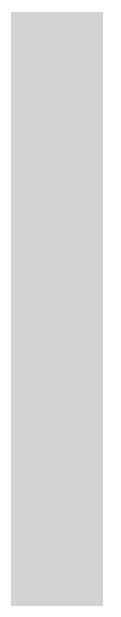

\section{Политика и реформы в области здравоохранения в Центральной и Восточной Европе}

\author{
Проф. Ю. Немец, проф. М. Бел \\ University Banska Bystrica, Slovakia
}

Проведенный анализ основан на примерах из многих стран в регионе, полученных из существующих документов. Упор сделан на наиболее развитых странах - новых членах Европейского союза, особенно Словакии и Чехии, но данные из менее развитых стран включены также. Основной целью реформ является равный всеобщего доступа к медицинской помощи высшего качества для всех. Несмотря на то что при реформах в Центральной и Восточной Европе подчеркивалась необходимость улучшения профилактики, небольшие изменения произошли в действительности, так как имеющиеся лобби предпочитают дорогие процедуры дешевым профилактическим мероприятиям.

Ключевые слова: здравоохранения, Европа, реформы. 


\title{
Політика та реформи в галузі охорони здоров'я в Центральній і Східній Європі
}

\author{
Проф. Ю. Немец, проф. М. Бел
}

University Banska Bystrica, Slovakia

Проведений аналіз заснований на прикладах з багатьох країн в регіоні, отриманих 3 існуючих документів. Упор зроблений на найбільш розвинених країнах - нових членах Європейського союзу, особливо Словаччини та Чехії, але дані з менш розвинених країн включені також. Основною метою реформ є рівний загальний доступ до медичної допомоги вищої якості для всіх. Незважаючи на те що при реформах в Центральній і Східній Європі підкреслювалася необхідність поліпшення профілактики, невеликі зміни відбулися в дійсності, так як наявні лобі віддають перевагу дорогим процедурам над дешевими профілактичними заходами.

Ключові слова: охорона здоров'я, Свропа, реформи.

Контактна інформація: prof. Juraj Nemec, University Banska Bystrica, Slovakia, e-mail: juraj.nemec@umb.sk.

Стаття поступила до редакції 12.02.2015 p.

\section{Рекоменаації Української асоціації кардіологів 3 Аіагностики, мікування та профімактики хронічної серцевої недостатності у дорослих (скорочений варіант)}

Робоча група: проф. Л.Г. Воронков - модератор (Київ); член-кор. АМНУ, проф. К.М. Амосова (Київ); проф. А.Е. Багрій (Донецьк); акад. АМНУ, проф. Г.В. Дзяк (Дніпропетровськ); проф. О.І. Дядик (Донецьк); проф. О.Й. Жарінов (Київ); акад. АМНУ, проф. Г.В. Книшов (Київ); членкор. АМНУ, проф. В.М. Коваленко (Київ); акад. АМНУ, проф. О.В. Коркушко (Київ).

\begin{abstract}
$\mathrm{X}_{\mathrm{se}}^{\mathrm{p}}$ ронічна серцева недостатність $(\mathrm{XCH})$ - значна медико-соціальна проблема, в тому числі в Україні. За даними національних реєстрів європейських країн та епідеміологічних досліджень показник поширеності ХCH серед дорослого населення коливається у межах $1-5 \%$ та зростає пропорційно до віку, становлячи понад $10 \%$ серед осіб віком понад 65 років.

Близько 50\% таких пацієнтів помирає протягом $\mathrm{D}_{4}$ років. Серед хворих з тяжкою ХСН смертність протягом найближчого року сягає 50\%. Лікування хворих на ХCH вимагає значних коштів - 1-2\% загальних витрат на охорону здоров'я в індустріально розвинених країнах, 2/3 з яких припадають на стаціонарне лікування пацієнтів, госпіталізованих з приводу декомпенсації кровообігу. 3 огляду на тенденцію, в тому числі й в Україні, до зростання питомої
\end{abstract}

ваги населення старших вікових груп, питання щодо надання медичної допомоги хворим на ХCH стає дедалі більш актуальним.

Ці рекомендації - офіційний консенсус-документ провідних експертів України з проблеми серцевої недостатності $(\mathrm{CH})$. У них не висвітлюються аспекти патогенезу, діагностики та лікування гострої $\mathrm{CH}$, оскільки останні детально розглянуто в окремих рекомендаціях Європейського товариства кардіологів.

Визначення серцевої недостатності

- Під СН розуміють патофізіологічний стан, при якому серце внаслідок порушення насосної функції не може задовольняти потреби метаболізму тканин.

- ХСН - клінічний синдром, типовими ознаками якого є прогресуючі зниження толерантності до фізичних навантажень, затримка в організмі рідини та зменшення тривалості життя. 